\title{
Ciprofloxacin decreases the rate of ethanol elimination in humans
}

\author{
J Tillonen, N Homann, M Rautio, H Jousimies-Somer, M Salaspuro
}

\begin{abstract}
Background-Extrahepatic ethanol metabolism is postulated to take place via microbial oxidation in the colon, mediated by aerobic and facultative anaerobic bacteria.

Aims-To evaluate the role of microbial ethanol oxidation in the total elimination rate of ethanol in humans by reducing gut flora with ciprofloxacin.

Methods-Ethanol was administered intravenously at the beginning and end of a one week period to eight male volunteers. Between ethanol doses volunteers received $750 \mathrm{mg}$ ciprofloxacin twice daily.

Results-A highly significant $(\mathrm{p}=0.001)$ reduction in the ethanol elimination rate (EER) was detected after ciprofloxacin medication. Mean (SEM) EER was 107.0 (5.3) and $96.9(4.8) \mathrm{mg} / \mathrm{kg} / \mathrm{h}$ before and after ciprofloxacin, respectively. Faecal Enterobacteriaceae and Enterococcus sp. were totally absent after medication, and faecal acetaldehyde production capacity was significantly $(p<0.05)$ decreased from $0.91(0.15)$ to $0.39(0.08) \mathrm{nmol} / \mathrm{min} / \mathrm{mg}$ protein. Mean faecal alcohol dehydrogenase (ADH) activity was significantly $(p<0.05)$ decreased after medication, but ciprofloxacin did not inhibit human hepatic ADH activity in vitro.

Conclusions-Ciprofloxacin treatment decreased the ethanol elimination rate by $9.4 \%$, with a concomitant decrease in intestinal aerobic and facultative anaerobic bacteria, faecal ADH activity, and acetaldehyde production. As ciprofloxacin has no effect on liver blood flow, hepatic ADH activity, or cytochrome CYP2E1 activity, these effects are probably caused by the reduction in intestinal flora. (Gut 1999;44:347-352)
\end{abstract}

Alcohol Diseases, University of Helsinki, Tukholmankatu $8 \mathrm{~F}$, 00290 Helsinki, Finland

J Tillonen

N Homann

M Salaspuro

Anaerobe Reference Laboratory, National Public Health Institute, Helsinki, Finland

M Rautio

H Jousimies-Somer

Correspondence to: Professor Salaspuro.

Accepted for publication 23 September 1998 nol is metabolised by cytosolic ADH. ${ }^{2}$ The contribution of the MEOS to ethanol elimination is limited, and only a minor part $(1-5 \%)$ of the total metabolism in vivo is carried out by the cytochrome P450 dependent MEOS. ${ }^{3}$
Liver catalase can oxidise ethanol in vitro, but under physiological conditions catalase appears to play only a minor role in ethanol metabolism. ${ }^{2}$

Extrahepatic elimination of ethanol does, however, also occur. To a smaller extent, ethanol is oxidised to acetaldehyde in other tissues possessing $\mathrm{ADH}$ activity, such as the stomach, small intestine, colon, kidneys, and lungs. ${ }^{4}$ In rats, the extrahepatic gastrointestinal metabolism of circulating ethanol has been shown to be up to $30 \%$ of that in the liver. ${ }^{5}$ Furthermore, in patients with cirrhosis of the liver, extrahepatic elimination has been estimated to constitute about $40 \%$ of the total ethanol elimination. ${ }^{6}$

Due to its high water solubility, ethanol levels inside the terminal ileum ${ }^{7}$ and colon $^{8}$ are equal to those of the blood. We have recently shown in experimental animals that ethanol can be oxidised via the aerobic and facultative anaerobic bacteria in the large intestine. ${ }^{9}$ Most of the luminal bacteria are anaerobic, and without oxygen they are capable of producing energy through fermentation. ${ }^{10}$ In alcoholic fermentation the end product is ethanol, which is derived from acetaldehyde in a reductive reaction mediated by bacterial ADH. ${ }^{11}$ However, oxygen diffuses through the colonic mucosa, and, accordingly, the human gut contains a mucosa associated microflora in which the number of aerobic and facultative anaerobic bacteria is almost comparable ${ }^{12}$ to that of anaerobic bacteria. Under these conditions and in the presence of exogenous ethanol, the $\mathrm{ADH}$ mediated bacterial reaction can oxidise ethanol to acetaldehyde in a reaction in which nicotinamide adenine dinucleotide (NAD) acts as an electron acceptor. ${ }^{13}$ Microbial catalases, in the presence of $\mathrm{H}_{2} \mathrm{O}_{2}$, can also oxidise ethanol to acetaldehyde. ${ }^{14}$

Ciprofloxacin possesses excellent in vitro and in vivo antibacterial activities against most aerobic and facultative anaerobic bacteria, including Enterobacteriaceae. ${ }^{1516}$ Furthermore, ciprofloxacin is partly eliminated through the intestinal wall, ${ }^{17}$ and the concentrations of ciprofloxacin in the faeces and intestinal mucosa are higher than the corresponding serum levels. ${ }^{18}$ This transintestinal elimination pattern may explain the ability of this drug to modify the colonic flora.

Treatment with ciprofloxacin was recently shown to reduce the rate of ethanol elimination by $9 \%$ in rats, and this was associated with a

Abbreviations used in this paper: $\mathrm{ADH}$, alcohol dehydrogenase; EER, ethanol elimination rate; GOX, glucose oxidase; MEOS, microsomal ethanol oxidising system; NAD, nicotinamide adenine dinucleotide. 
reduction in faecal aerobic flora and faecal ADH activity. ${ }^{19}$ The aim of the present study was to evaluate the role of microbial ethanol oxidation in the total elimination of ethanol in man by reducing human gut flora with ciprofloxacin. The second aim was to study possible changes in faecal flora and faecal enzyme activities participating in both ethanol oxidation and acetaldehyde production before and after administration of ciprofloxacin for one week.

\section{Materials and methods} SUBJECTS

After approval by the Ethical Committee at the University Central Hospital of Helsinki, eight healthy men, with an age range of 21-31 years participated in the in vivo studies. Mean body weight was 78 (3) $\mathrm{kg}$, and body mass index $23.8(0.4) \mathrm{kg} / \mathrm{m}^{2}$. None of the subjects had received any antibiotics for four weeks preceding the study or was using any other drugs during the study days. One of the subjects was a light smoker. All were moderate consumers of alcohol, with a weekly average consumption of $70 \mathrm{~g}$ or less of ethanol. All participants were told to refrain from ethanol for at least 36 hours before the study.

\section{STUDY DESIGN}

A paired design in which each subject served as his own control was used (open, nonrandomised, no placebo control). Two study days were separated by a one week interval. The volunteers were admitted to the University Central Hospital of Helsinki, and all studies started between 800 and 900 am. Two intravenous lines (Viggo, $1.22 \mathrm{~mm} / 18 \mathrm{G} \mathrm{L} 32 \mathrm{~mm}$, BOC Ohmeda AB, Helsingborg, Sweden) were placed into the antecubital veins at the beginning of each study day, one for the administration of ethanol and one for obtaining repeated blood samples. Ethanol $(0.63 \mathrm{~g} / \mathrm{kg}$ body weight) was mixed in 5\% glucose solution at $7 \%$ concentration and was administered at a constant rate over a 30 minute period intravenously. This application was chosen to avoid the influence of the first pass metabolism and alterations in gastric motility on ethanol pharmacokinetics. Eating and smoking were prohibited during the study. Blood samples (3 $\mathrm{ml})$ were taken into vacutainer tubes containing $0.06 \mathrm{ml}$ EDTA for measurement of blood alcohol levels by head space gas chromatography. Baseline samples were taken before ethanol administration had started (time 0) and at five minute intervals during the first hour, at 15 minute intervals during the second hour, and at 20 minute intervals until the breath ethanol analyser (Lion Laboratories, Barry, UK) showed no detectable blood ethanol levels. The protocol was exactly the same on both study days. During the seven days between the experiments, the volunteers received $750 \mathrm{mg}$ ciprofloxacin (Ciproxin, Bayer AG, Leverkusen, Germany) orally twice a day. The drug intake was started on the evening of the first infusion day and the last tablet was taken one hour prior to the administration of intravenous ethanol on the second study day.
Faecal samples were collected before and after medication, and samples were frozen to $-80^{\circ} \mathrm{C}$ within six hours.

BACTERIAL ANALYSIS

The faecal samples were thawed, and $1 \mathrm{~g}$ of each specimen was suspended and serially diluted (10-fold) from $10^{-1}$ to $10^{-6}$ in peptone yeast extract broth. Undiluted sample and a 10 $\mu \mathrm{l}$ aliquot of the appropriate dilutions were inoculated and spread on several selective and non-selective agar media for the enumeration and isolation of total counts and main groups of aerobic and anaerobic bacteria and yeasts. The aerobic plates were incubated at $35^{\circ} \mathrm{C}$ in an atmosphere containing $5 \% \mathrm{CO}_{2}$ for up to five days; anaerobic plates were incubated in anaerobic jars filled with the evacuation replacement method with mixed gas $\left(90 \% \mathrm{~N}_{2}\right.$, $5 \% \mathrm{CO}_{2}, 5 \% \mathrm{H}_{2}$ ) for seven days for the first inspection and up to 14 days for the final inspection. The sensitivity of this method was 3000 colony forming units (cfu)/g faeces. The bacteria were enumerated and identified by established methods. ${ }^{20} 21$

FAECAL ACETALDEHYDE PRODUCTION

To measure acetaldehyde production capacity, faecal samples were lyophilised for 24 hours (Micromodulyo $1.5 \mathrm{~K}$ Freeze Dryer, RV5 Rotatory Vane Pump, Edwards High Vacuum Int., UK). Thereafter dried faecal samples were dissolved in $0.1 \mathrm{M}$ potassium phosphate (KPO) buffer ( $\mathrm{pH}$ 7.4) at a concentration of 20 $\mathrm{mg} / \mathrm{ml}$. To obtain supernatant, the solution was first homogenised $\left(10 \times 5\right.$ seconds, $1200 \mathrm{~min}^{-1}$; Potter S Homogenizer, B. Braun Melsungen AG, Germany) and then sonicated $(8 \times 20 \mathrm{sec}-$ onds, $20 \mathrm{kHz}$, Sonics \& Materials, USA), surrounded by ice to avoid protein coagulation. This was followed by centrifugation of the sonicate at $100000 \mathrm{~g}$ at $5^{\circ} \mathrm{C}$ for 60 minutes, and supernatant was collected and used for measurements. A $250 \mu \mathrm{l}$ aliquot of supernatant was incubated for 60 minutes in closed glass vials with $50 \mu \mathrm{l}$ ethanol/buffer mixture (final concentration $22 \mathrm{mM}$ ethanol, $0.1 \mathrm{M} \mathrm{KPO}$ buffer, $\mathrm{pH} 7.4$ ) at $37^{\circ} \mathrm{C}$ after adding different coenzymes. The coenzymes used were nicotinamide adenine dinucleotide (NAD; final concentration in the reaction mixture $3 \mathrm{mM}$ ) to activate $\mathrm{ADH}$, glucose oxidase (GOX; final concentration $0.03 \mu \mathrm{mol} / \mathrm{min}$ ) and glucose (final concentration $10 \mathrm{mM}$ ) to produce hydrogen peroxide $\left(\mathrm{H}_{2} \mathrm{O}_{2}\right)$ and to activate catalase, or both. All the reagents were obtained from Sigma Chemical Co. (St Louis, Missouri, USA). Reactions were stopped by injecting 50 $\mu 1$ of $6 \mathrm{~mol} / 1$ perchloric acid (PCA) through the rubber septum of the vial; the final volume in vials was $500 \mu \mathrm{l}$. Acetaldehyde was analysed using headspace gas chromatography as described previously. ${ }^{22}$ To control for nonenzymatic artefactual acetaldehyde formation from ethanol during the protein precipitation, ${ }^{23}$ PCA was added simultaneously with ethanol into additional incubation vials (incubation time 0 ) and the revealed values were subtracted from acetaldehyde values obtained after the 60 minute incubation period. Acetaldehyde 
Table 1 Effects of ciprofloxacin on ethanol pharmacokinetics

\begin{tabular}{llll}
\hline & Before CIP & After CIP & p Value \\
\hline Peak ethanol $(\mathrm{mM})$ & $22.47(1.00)$ & $23.27(1.26)$ & NS \\
$\mathrm{V}_{\mathrm{d}}(\mathrm{l} / \mathrm{kg})$ & $0.70(0.02)$ & $0.70(0.02)$ & $\mathrm{NS}$ \\
$\mathrm{C}_{0}(\mathrm{mM})$ & $19.68(0.54)$ & $19.71(0.58)$ & $\mathrm{NS}$ \\
$\mathrm{EER}(\mathrm{mg} / \mathrm{kg} / \mathrm{h})$ & $107.0(5.3)$ & $96.9(4.8)$ & 0.001 \\
$\mathrm{AUC}(\mathrm{mM} / \mathrm{h})$ & $58.9(2.9)$ & $65.5(3.3)$ & 0.0004 \\
Time 0 $(\mathrm{h})$ & $5.99(0.31)$ & $6.61(0.32)$ & 0.0003
\end{tabular}

Results expressed as mean (SEM).

CIP, ciprofloxacin.

production was related to the protein concentration of the supernatant determined by the method of Lowry et al. ${ }^{24}$

FAECAL ENZYME ACTIVITIES

To measure ethanol oxidising enzymes, ADH and catalase, supernatant, prepared as above, was used. ADH activity of the supernatant was determined spectrophotometrically by following the reduction of NAD (final concentration $3 \mathrm{mM}$ in $0.1 \mathrm{M} \mathrm{KPO}, \mathrm{pH} 7.4$ ) using $25 \mathrm{mM}$ or $1.5 \mathrm{M}$ ethanol (in $\mathrm{KPO}$ ) at $37^{\circ} \mathrm{C}$. Catalase activity of the supernatant was determined spectrophotometrically at $240 \mathrm{~nm}$ after the addition of $10 \mathrm{mM} \mathrm{H}_{2} \mathrm{O}_{2}$ at $37^{\circ} \mathrm{C}$ (in $0.1 \mathrm{M}$ $\mathrm{KPO}, \mathrm{pH}$ 7.4). ${ }^{25}$ Enzyme activities were related to the protein concentrations of the supernatant.

HEPATIC ADH ACTIVITY

Human liver tissue was obtained from a patient undergoing surgery. Liver tissue was first homogenised in the ratio of $1: 4$ (in $0.1 \mathrm{M}$ $\mathrm{KPO}, \mathrm{pH}$ 7.4) The homogenate was then centrifuged at $1000 \mathrm{~g}$ at $4^{\circ} \mathrm{C}$ for 10 minutes, followed by centrifugation at $100000 \mathrm{~g}$ at $5^{\circ} \mathrm{C}$ for 60 minutes to obtain cytosol. Cytosolic $\mathrm{ADH}$ activity was determined spectrophotometrically by following the reduction of NAD (final concentration $3 \mathrm{mM}$ in $0.1 \mathrm{M} \mathrm{KPO}, \mathrm{pH}$ 7.4) using $25 \mathrm{mM}$ ethanol (in $\mathrm{KPO}$ ). The effect of ciprofloxacin on $\mathrm{ADH}$ activity was tested by adding increasing drug concentrations (final concentrations $1,10,20 \mu \mathrm{g} / \mathrm{l}$ ) to the buffer used.

PHARMACOKINETICS OF ETHANOL IN BLOOD The concentration-time profiles of ethanol were evaluated according to zero order kinetics. This pharmacokinetic model assumes a rectilinear disappearance of ethanol from blood after the absorption and distribution of the dose is completed. The $y$ intercept of the regression line $\left(\mathrm{C}_{0}\right)$ is the concentration of ethanol in blood if the dose of $0.63 \mathrm{~g} / \mathrm{kg}$ was distributed into total body water immediately after the infusion started. The ratio of dose of ethanol $(\mathrm{g} / \mathrm{kg})$ divided by the parameter $\mathrm{C}_{0}$ is the apparent volume of distribution of ethanol $\left(V_{d}\right)$. The ethanol elimination rate (EER) from the body was obtained by dividing the dose given $(0.63 \mathrm{~g} / \mathrm{kg})$ by the estimated time of reaching zero concentration of ethanol in blood $\left(\right.$ time $\left._{0}\right)$. The time 0 parameter corresponds to the $x$ intercept of the concentration-time regression equation. The areas under the concentration-time profiles (AUCs) were determined by the trapezoidal method from the beginning of ethanol administration to the time when it was no longer detectable.

\section{STATISTICAL ANALYSIS}

The results are expressed as mean (SEM). The statistical significance of the differences before and after the ciprofloxacin intake was analysed by Student's paired $t$ test. A p value of less than 0.05 was considered to be significant. The possible correlations were tested by using simple linear regression analysis.

\section{Results}

EFFECT OF CIPROFLOXACIN ON ETHANOL PHARMACOKINETICS

Figure 1 represents the mean (SEM) values of the concentration-time profiles of ethanol in blood and regression lines to the elimination phase of the curves for eight subjects. Table 1 summarises the pharmacokinetic parameters of ethanol derived from blood concentrationtime data. The time to reach zero ethanol concentration in blood (time ${ }_{0}$ ) increased after ciprofloxacin medication, and accordingly there was a highly significant decrease $(p=0.001)$ in the EER. The mean (SEM) ethanol elimination rates were $107.0(5.3) \mathrm{mg} / \mathrm{kg} / \mathrm{h}$ before the ciprofloxacin treatment and $96.9(4.8) \mathrm{mg} / \mathrm{kg} / \mathrm{h}$ after treatment for one week. The overall decrease in EER was $9.4 \%$. The individual rate of ethanol elimination decreased in all volunteers (fig 2). The highest decrease in EER was $17.6 \%$ and the lowest $5.1 \%$.
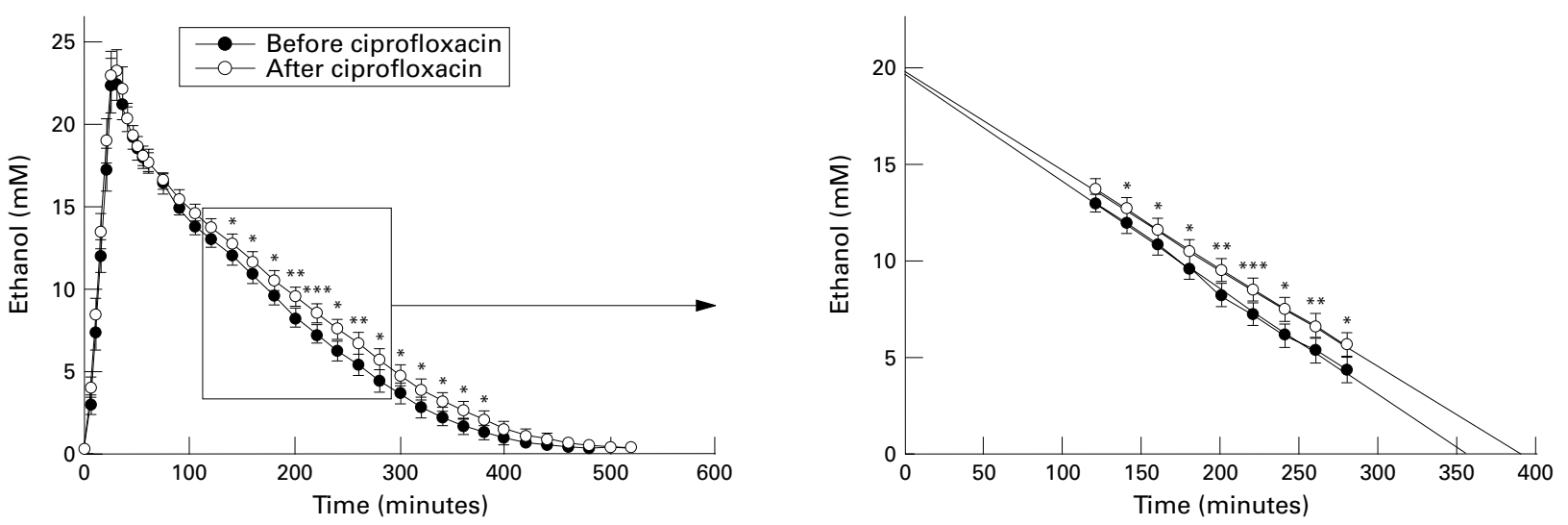

Figure 1 Blood ethanol concentrations (mean (SEM)) before and after ciprofloxacin treatment. ${ }^{\star} p<0.05,{ }^{\star *} p<0.001,{ }^{\star \star *} p<0.0001$. 


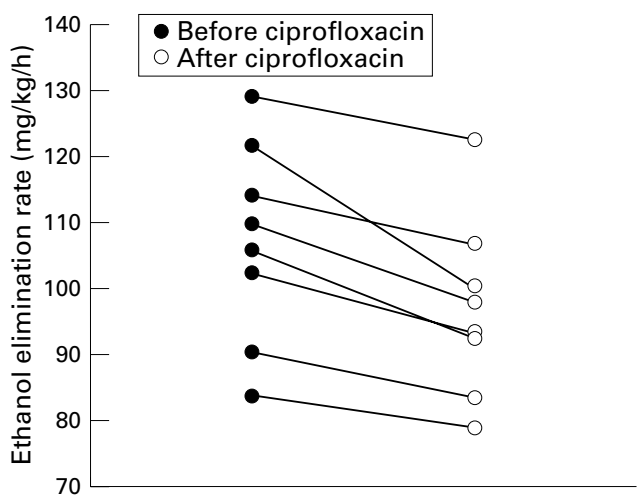

Figure 2 The effect of ciprofloxacin treatment $(750 \mathrm{mg}$ twice a day) for seven days on individual ethanol elimination rates in eight volunteers.

Table 2 Effects of ciprofloxacin on faecal bacteriological counts

\begin{tabular}{lll}
\hline & Before CIP & After CIP \\
\hline Anaerobes & & \\
Total counts & $3.5 \times 10^{-9}$ & $6.9 \times 10^{-8}$ \\
Bifidobacterium sp. & $4.3 \times 10^{-8}$ & $2.6 \times 10^{-4}$ \\
B fragilis-gr & $3.8 \times 10^{-8}$ & $3.2 \times 10^{-8}$ \\
Clostridium sp. & $6.2 \times 10^{-5}$ & $8.9 \times 10^{-4}$ \\
Aerobes & & \\
Total count & $1.1 \times 10^{-8}$ & $6.5 \times 10^{-6}$ \\
Enterobacteriaceae & $1.0 \times 10^{-8}$ & 0 \\
Enterococcus sp. & $1.2 \times 10^{-6}$ & 0 \\
Streptococcus sp. & $1.2 \times 10^{-6}$ & $5.1 \times 10^{-4}$ \\
Staphylococcus sp. & $1.3 \times 10^{-3}$ & $8.8 \times 10^{-4}$ \\
Lactobacillus sp. & $4.9 \times 10^{-6}$ & $6.1 \times 10^{-6}$ \\
Corynebacterium sp. & $1.5 \times 10^{-6}$ & $1.0 \times 10^{-4}$ \\
\hline
\end{tabular}

Results expressed as mean cfu/g $(n=8)$.

CIP, ciprofloxacin.

EFFECT OF CIPROFLOXACIN ON FAECAL BACTERIA Ciprofloxacin treatment for seven days produced a clear decline in the number of faecal aerobic bacteria from $1.1 \times 10^{8} \mathrm{cfu} / \mathrm{g}$ to $6.5 \times$ $10^{6} \mathrm{cfu} / \mathrm{g}$ ( $\mathrm{p}=0.04$, Wilcoxon signed rank test). Before drug intake, Enterobacteriaceae was the predominant aerobic flora present in every volunteer. Enterococcus sp. were found in five of the eight subjects. After ciprofloxacin these species totally disappeared from the stool samples. Streptococcus sp. were initially present in five subjects, Staphylococcus sp. in one, Lactobacillus $\mathrm{sp}$. in three, and Corynebacterium sp. in four subjects. These bacteria responded variably, either disappearing in some cases, persisting in others, or even arising after medication. Yeasts were not originally present in any volunteer, but appeared at levels of $1.0 \times 10^{4}$ and $6 \times 10^{4}$

Table 3 Effects of ciprofloxacin on faecal enzyme activities

\begin{tabular}{llll}
\hline & Before CIP & After CIP & p Value \\
\hline ADH $(25 \mathrm{mM})$ & $1.17(0.31)$ & $0.47(0.12)$ & 0.013 \\
ADH $(1.5 \mathrm{M})$ & $2.98(0.28)$ & $1.28(0.17)$ & 0.006 \\
Catalase & $75.42(8.97)$ & $56.56(8.76)$ & NS \\
\hline
\end{tabular}

Enzyme activities expressed as nmol NADH/min/mg protein for $\mathrm{ADH} ; \mathrm{nmol} / \mathrm{min} / \mathrm{mg}$ protein for catalase.

CIP, ciprofloxacin

Table 4 Effect of ciprofloxacin on faecal acetaldehyde production

\begin{tabular}{llll}
\hline & Before CIP & After CIP & p Value \\
\hline After the addition of NAD & $0.91(0.15)$ & $0.39(0.08)$ & 0.007 \\
After the addition of GOX & $0.35(0.06)$ & $0.35(0.05)$ & NS \\
After the addition of both & $0.94(0.14)$ & $0.57(0.06)$ & 0.044 \\
\hline
\end{tabular}

Results expressed as $\mathrm{nmol} / \mathrm{min} / \mathrm{mg}$ protein

CIP, ciprofloxacin. $\mathrm{cfu} / \mathrm{g}$ in two subjects out of eight after ciprofloxacin administration. The total count of anaerobic bacteria declined slightly. This was mainly due to a drop in the number of Bifidobacterium sp., initially present in six subjects, and present after ciprofloxacin administration in three of eight subjects. Table 2 summarises the bacteriological results for the faecal samples.

\section{EFFECT OF CIPROFLOXACIN ON FAECAL ENZYMES} AND ACETALDEHYDE PRODUCTION

The mean $\mathrm{ADH}$ activity of the faecal samples measured before ciprofloxacin treatment was significantly $(p<0.05)$ higher at both ethanol concentrations than that of the samples taken after treatment (table 3). The high ethanol concentration was used in order to saturate all microbial ADH isoenzymes. The catalase activity, however, remained unchanged after ciprofloxacin dosing (table 3 ). The acetaldehyde production capacity of the faecal samples also decreased significantly after ciprofloxacin treatment when NAD was used as a cofactor to activate $\mathrm{ADH}$, but remained unaltered when glucose + glucose oxidase was used to activate catalase (table 4).

Ciprofloxacin did not have any significant in vitro effect on the activity of human hepatic $\mathrm{ADH}$ at the concentrations used. $\mathrm{ADH}$ activity was $100.3 \%, 98.9 \%$, and $102.5 \%$ compared with the control samples without the drug, when 1,10 , and $20 \mu \mathrm{g} / 1$ (final concentrations) of ciprofloxacin, respectively, were used.

Although the individual rate of ethanol elimination decreased in all subjects, no correlation could be found between the decrease in the individual EERs and the reduction in bacterial counts. On the other hand, there was a statistically significant positive correlation $(r=0.75, \mathrm{p}<0.001)$ between faecal ADH activity at $1.5 \mathrm{M}$ ethanol and acetaldehyde production from ethanol.

\section{Discussion}

This study shows that treatment with ciprofloxacin for one week reduces the ethanol elimination rate in man by $9.4 \%$ without affecting the apparent volume of distribution. The intravenous administration of ethanol excludes the possible effects of altered gastric emptying and gastric first pass metabolism on ethanol pharmacokinetics. ${ }^{26}$ Ciprofloxacin did not inhibit hepatic $\mathrm{ADH}$ activity in vitro in concentrations exceeding serum concentrations ${ }^{18}$ known to exist in the liver tissue during treatment. ${ }^{27}$ Ciprofloxacin has, however, been reported to reduce the hepatic metabolism of coadministered xanthines, such as theophylline and caffeine, leading to increased serum concentrations and reduced elimination of these substances. ${ }^{28}$ The mechanism behind this effect has been suggested to be the specific inhibition of CYP1A2 activity. ${ }^{29}$ In addition, ciprofloxacin decreases cytochrome CYP3A4 mediated biotransformation, but it does not inhibit the metabolism of substrates that are specific for the CYP2E1 and CYP4A1 isoenzymes. ${ }^{30}$ The isoenzyme CYP2E1 is the major contributor to the MEOS in humans, 
although CYP1A2 has also been considered to play a role. ${ }^{31}$ Thus the inhibitory effect of ciprofloxacin on the ethanol elimination rate could at least partly be the consequence of the drug's interference with cytochrome mediated ethanol oxidation. The contribution of the MEOS to ethanol metabolism, however, is at most $5 \% .^{3}$ Hence it is obvious that possible interactions between ciprofloxacin and ethanol oxidising enzymes in the liver can explain only a small part of the reduction in the ethanol elimination rate. Hepatic metabolism of ethanol may also be reduced because of the changes in hepatic blood flow. Ciprofloxacin, however, has no effect on the clearance of indocyanine green, a dye highly extracted by the liver, which indicates a lack of effect on hepatic blood flow. ${ }^{32}$ Thus the decrease in ethanol elimination found in this study is unlikely to be the result of decreased hepatic blood flow.

It has been shown in earlier experiments that human colonic contents are capable of producing significant amounts of acetaldehyde when incubated with ethanol concentrations known to exist in the colon during social drinking. ${ }^{22}$ Furthermore, many aerobic Gram negative bacteria belonging to the family Enterobacteriaceae and representing normal colonic flora in man possess notable NAD dependent $\mathrm{ADH}$ activity, and are able to produce significant amounts of acetaldehyde when incubated in vitro with ethanol. ${ }^{33}$ In vivo microbially derived ethanol oxidation and acetaldehyde production have been shown to occur in rats with a self filling diverticulum and concomitant bacterial overgrowth, ${ }^{34}$ and in the colon of pigs. ${ }^{35}$ These findings strongly suggest that intestinal microbes are able to oxidise ethanol by a bacteriocolonic pathway for ethanol oxidation. ${ }^{9} 3536$

The results of this study suggest that the decrease in ethanol elimination produced by ciprofloxacin is most probably due to the reduction in gut aerobic flora and the consequent inhibition of ethanol oxidation via colonic bacteria. The findings from the bacteriological analysis support this hypothesis. The species of the family Enterobacteriaceae, which has been shown to possess $\mathrm{ADH}$ activity and to produce acetaldehyde from ethanol in vitro, ${ }^{33}$ disappeared from the stool after ciprofloxacin treatment. Also, Enterococcus species were absent after medication. The bacterial flora of the human large intestine forms an extremely complex ecosystem, and there is almost never empty territory in the gut. When one compartment of this ecosystem is disturbed, other bacterial strains grow and fill this bare area. As can been seen in this study, the number of Lactobacillus species, which have been shown to be able to metabolise ethanol to acetaldehyde poorly, ${ }^{37}$, were unchanged. In addition, the number of Staphylococcus species were even more numerous after the medication. The growth of other aerobic microbes that are not capable of ethanol oxidation probably makes it impossible to find any correlations between the decrease in the individual EERs and the reduction in total bacterial counts.
This is the first study to show that human stool samples possess ADH and catalase activities and produce acetaldehyde from ethanol in vitro. The faecal ADH activity and acetaldehyde production capacity decreased significantly after ciprofloxacin treatment for one week, whereas catalase activity remained unaltered. Furthermore, there was a significant correlation between faecal $\mathrm{ADH}$ activity and acetaldehyde production. These results strongly suggest that ethanol oxidation by colonic bacteria in man is mainly due to $\mathrm{ADH}$ associated reactions.

Jokelainen et al recently reported a 9\% $(p<0.02)$ reduction in ethanol elimination in rats after high dose ciprofloxacin treatment for four days, with a concomitant decrease in faecal aerobic bacteria and $\mathrm{ADH}$ activity; yet an acute intraperitoneal dose of ciprofloxacin 60 minutes prior to ethanol administration had no effect on the rate of ethanol elimination. ${ }^{19}$ This implies that ciprofloxacin itself and/or its metabolites have no effect on the hepatic clearance of ethanol in vivo in rats. Neither were rat hepatic ADH nor MEOS activities affected by the ciprofloxacin treatment. This animal study supports our present findings regarding humans. In contrast, another human study with ciprofloxacin $(500 \mathrm{mg}$ twice a day for three days) showed no effect on ethanol pharmacokinetics (AUC, EER, peak ethanol concentration) after an oral ethanol dose of $0.38 \mathrm{~g} / \mathrm{kg} .^{38}$ In that study, as well in the present one, the last dose of ciprofloxacin was taken one hour prior to the administration of ethanol. The explanation for these contradictory findings could be the notable interindividual variations $( \pm 20 \%)$ in ethanol elimination rates. In order to eliminate the effects of this variation we used a study design in which each volunteer served as his own control. This enables detection of small differences in EER that might be hidden in a placebo controlled study if the sample size is too small. An additional explanation is that in the earlier study the dosage of the drug was lower and the duration of medication shorter than in our study. Accordingly, it is possible that the elimination of colonic flora was not sufficient to reach the rate limiting threshold for bacterial ethanol oxidation. Due to a higher ciprofloxacin dose we cannot entirely rule out the possibility that other factors, such as interactions with cytochrome enzymes, might also have influenced the results.

Bacterial ethanol oxidation is a novel finding and of interest for the field of gastroenterology. It has been shown previously that intracolonically formed acetaldehyde is only poorly metabolised by colonic mucosa, ${ }^{39} 40$ and bacteria ${ }^{41}$ and that it can also be transported to the liver via portal circulation. ${ }^{42}$ There is evidence that a low dose of acetaldehyde delivered to rats in drinking water produces microvesicular fatty infiltration of the liver even in the absence of ethanol. ${ }^{42}$ Accordingly, acetaldehyde of extrahepatic origin (formed by bacterial $\mathrm{ADH}$ from ethanol in the colon), may contribute to the pathogenesis of alcoholic liver disease. Furthermore, intracolonically formed acetaldehyde may increase intestinal 
permeability, ${ }^{43}$ and chronic alcoholism may alter the composition of gut flora. ${ }^{44}$ These factors may lead to elevated blood endotoxin levels ${ }^{45}$ and may thereby contribute to the pathogenesis of alcoholic liver disease, ${ }^{46}{ }^{47}$ suggesting the use of antibiotics in the treatment of such disease. Nevertheless, we cannot exclude the possibility that the bacteriocolonic pathway for ethanol oxidation may also protect the liver by decreasing its exposure to ethanol.

In conclusion, ciprofloxacin treatment decreases the ethanol elimination rate by $9.4 \%$ in man, with a concomitant decrease in faecal $\mathrm{ADH}$ activity and acetaldehyde production in vitro. Due to a lack of evidence that ciprofloxacin interferes with hepatic ethanol metabolism, our findings can be explained by the reduction in aerobic and facultative anaerobic bacteria in the lumen and mucosal surfaces of the human large intestine. These findings support evidence of the significant role of colonic bacteria in extrahepatic ethanol metabolism and acetaldehyde production in man. It further supports the new microbiological approach to the pathogenesis of alcohol related gastrointestinal diseases. This study was supported financially by the Yrjö Jahnsson
Foundation, the Finnish Foundation for Alcohol Studies, the Foundation, the Finnish Foundation for Alcohol Studies, the Mildred Scheel Stiftung (Deutsche Krebshilfe EV), and the Minnish-Norwegian Foundation for Medicine.

1 Holford NHG. Clinical pharmacokinetics of ethanol. Clin Pharmacokinet 1987;13:273-92.

2 Lieber CS. Alcohol and the liver: 1994 update. Gastroenterology 1994;106:1085-105.

3 Ingelman-Sundberg M. Cytochrome P450 in alcohol metabolism. Alcohol Alcohol 1997;32:317.

4 Estonius M, Svensson S, Höög J-O. Alcohol dehydrogenase in human tissue: localisation of transcripts coding for five classes of the enzyme. FEBS Lett 1996;397:338-42.

5 Huang M-T, Huang C-C, Chen M-Y. In vivo uptake of ethanol and release of acetate in rat liver and GI. Life Sci 1993;53:165-70

6 Utne HE, Winkler K. Hepatic and extrahepatic elimination of ethanol in cirrhosis. Scand F Gastroenterol 1980;15:297304

7 Halstedt CH, Robles EA, Mezey E. Distribution of ethanol in the human gastrointestinal tract. Am $\mathcal{F}$ Clin Nutr 1973;26:831-4.

8 Levitt MD, Doizaki W, Levine AS. Hypothesis: metabolic activity of the colonic bacteria influences organ injury from activity of the colonic bacteria influences

9 Salaspuro M. Bacteriocolonic pathway for ethanol Salaspuro M. Bacteriocolonic pathway for ethanol
oxidation: characteristics and implications. Ann Med 1996; 28:195-200.

10 Cummings JH. Fermentation in the human large intestine: evidence and implications for health. Lancet 1983; ; 1206-8.

11 Neale AD, Scopes RK, Kelly JM, et al. The two alcoho dehydrogenases of Zymomonas mobilis. Purification by differential dye ligand chromatography, molecular characterisation and physiological roles. Eur f Biochem 1986;154 119-24.

12 Poxton IR, Brown R, Sawyerr A, et al. Mucosa-associated bacterial flora of the human colon. $f$ Med Microbio 1997; 46:85-91.

13 Stryer L. Glycolysis. In: Stryer L, ed. Biochemistry. 3rd edn. New York: WH Freeman, 1988:349-72.

14 MacFaddin JF. Catalase test. In: MacFaddin JF. Biochemical tests for identification of medical bacteria. Baltimore: Williams tests for identification of $m$.

15 Davis R, Markham A, Balfour JA. Ciprofloxacin. An updated review of its pharmacology, therapeutic efficacy and tolerability. Drugs 1996;51:1019-74.

16 Shah PM, Enzensberger R, Glogau O, et al. Influence of oral ciprofloxacin or ofloxacin on the fecal flora of healthy vol unteers. Am F Med 1987;82 (suppl 4A):333-5.

17 Rohwedder RW, Bergan T, Thorsteinsson SB, et al. Transintestinal elimination of ciprofloxacin. Diagn Microbiol Infect Dis 1990;13:127-33.

18 Brismar B, Edlund C, Malmborg A-S, et al. Ciprofloxacin concentrations and impact of the colon microflora in patients undergoing colorectal surgery. Antimicrob Agent Chemother 1990;34:481-3.
19 Jokelainen K, Nosova T, Koivisto T, et al. Inhibition of bacteriocolonic pathway for ethanol oxidation by ciprofloxacin in rats. Life Sci 1997;61:1755-62.

20 Summanen P, Baron EJ, Citron DM, et al. Wadsworth anaerobic bacteriology manual. 5 th edn. Belmont, California: Star Publishing, 1993.

21 Murray PR, Baron EJ, Pfaller MA, et al, eds. Manual of clinical microbiology. 6th edn. Washington DC: ASM Press, 1995.

22 Jokelainen $\mathrm{K}$, Roine $\mathrm{RP}$, Väänänen $\mathrm{H}$, et al. In vitro acetaldehyde formation by human colonic bacteria. Gut 1994:35:1271-4.

23 Stowell AR, Greenway RM, Batt RD. Acetaldehyde formation during deproteinization of human blood samples containing ethanol. Biochem Med 1977;18:392-401.

24 Lowry $\mathrm{OH}$, Rosenbrough NJ, Farr AL, et al. Protein measurement with folin phenol reagent. f Biol Chem 1951; 193:265-75.

25 Aebi H. Catalase. In: Bergmeyer HU, ed. Methods in enzymatic analysis. 3rd edn. Weinheim, FRG: Verlag Chemie, 1983:673-84.

26 Fraser AG. Pharmacokinetic interactions between alcohol and other drugs. Clin Pharmacokinet 1997;33:79-90.

27 Dan M, Verbin N, Gorea A, et al. Concentration of ciprofloxacin in human liver, gallbladder, and bile after oral administration. Eur f Clin Pharmacol 1987;32:217-18.

28 Radant JM, Marchbanks CR, Dudley MN. Interactions of fluoroquinolones with other drugs: mechanism, variability, clinical significance, and management. Clin Infect Dis 1992; 14:272-84.

29 Mizuki Y, Fujiwara I, Yamaguchi T. Pharmacokinetic interactions related to the chemical structures of fluoroquinolones. F Antimicrob Chemother 1996;37(suppl A):41-55.

30 McLellan RA, Drobitch RK, Monshouwer M, et al. Fluroquoinolone antibiotics inhibit cytochrome P450mediated microsomal drug metabolism in rat and human. Drug Metab Dispos 1996;24:1134-8.

31 Asai H, Imaoka S, Kuroki T, et al. Microsomal ethanol oxidizing system activity by human hepatic cytochrome P450s. F Pharmacol Exp Ther 1996;277:1004-9.

32 Nix DE, DeVito JM, Whitbread MA, et al. Effect of multiple dose oral ciprofloxacin on the pharmacokinetics of theophylline and indocyanine green. I Antimicrob Chemother 1987;19:263-9.

33 Jokelainen K, Siitonen A, Jousimies-Somer H, et al. In vitro alcohol dehydrogenase-mediated acetaldehyde production by aerobic bacteria representing the normal colonic flora in man. Alcohol Clin Exp Res 1996;20:967-72.

34 Baraona E, Julkunen RJK, Tannebaum L, et al. Role of intestinal bacterial overgrowth in ethanol production and metabolism in rats. Gastroenterology 1986;90:103-10.

35 Jokelainen K, Matysiak-Budnik T, Mäkisalo $\mathrm{H}$, et al. High intracolonic acetaldehyde levels produced by a bacteriocolonic pathway for ethanol oxidation in piglets. Gut 1996;39:100-4.

36 Salaspuro M. Microbial metabolism of ethanol and acetaldehyde and clinical consequences. Addict Biol 1997; 2:35-46.

37 Nosova T, Jokelainen K, Jousimies-Somer H, et al. Ethanol and acetaldehyde metabolism by Lactobacillus and Bifidobacterium strains representing normal human anaerobic colonic flora. Alcohol Alcohol 1996;31:323.

38 Kamali F. No influence of ciprofloxacin on ethanol disposition. A pharmacokinetic-pharmacodynamic interaction study. Eur f Clin Pharmacol 1994;47:71-4.

39 Yin S-J, Liao C-S, Lee Y-C, et al. Genetic polymorphism and activities of human colon alcohol and aldehyde dehydrogenases: no gender and age differences. Alcohol Clin Exp Res 1994;18:1256-60.

40 Koivisto T, Salaspuro M. Aldehyde dehydrogenases of the rat colon: comparison with other tissues of the alimentary tract and the liver. Alcohol Clin Exp Res 1996;20:551-5.

41 Nosova T, Jokelainen K, Kaihovaara P, et al. Aldehyde dehydrogenase activity and acetate production by aerobic bacteria representing the normal flora of human large intestine. Alcohol Alcohol 1996;31:555-64.

42 Matysiak-Budnik $\mathrm{T}$, Jokelainen $\mathrm{K}$, Kärkkäinen $\mathrm{P}$, et al. Hepatotoxicity and absorption of extrahepatic acetaldehyde in rats. F Pathol 1996;178:469-74.

43 Bjarnason I, Ward K, Peters TJ. The leaky gut of alcoholism: possible route of entry for toxic compounds. Lancet 1984;i: $179-82$

44 Bode JC, Bode C, Heidelbach R, et al. Jejunal microflora in patients with chronic alcohol abuse. Hepatogastroenterology 1984;31:30-4.

45 Fukui H, Brauner B, Bode JC, et al. Plasma endotoxin concentrations in patients with alcoholic and non-alcoholic liver disease: reevaluation with an improved chromogenic assay. F Hepatol 1991;12:162-9.

46 Nanji AA, Khettry U, Sadrzadeh SMH, et al. Severity of liver injury in experimental alcoholic liver disease. Correlation with plasma endotoxin, prostaglandin E2, leukotriene B4, and thromboxane B2. Am f Pathol 1993;142:367-73.

47 Adachi Y, Moore LE, Bradford BU, et al. Antibiotics prevent liver injury in rats following long-term exposure to ethanol. Gastroenterology 1995;108:218-24. 